Article

\title{
Investigating the Relative Performance of Bricks-and-Mortar, Clicks-and-Mortar, and Pure-Click Firms in Taiwan
}

\author{
Irene Y. L. Chen ${ }^{1}$ (D), Yi-Shun Wang ${ }^{2, *(\mathbb{D})}$ and Bo-Ruei Li ${ }^{1}$ \\ 1 Department of Accounting, National Changhua University of Education, Changhua 50074, Taiwan; \\ irene@cc.ncue.edu.tw (I.Y.L.C.); royli0825@hotmail.com (B.-R.L.) \\ 2 Department of Information Management, National Changhua University of Education, \\ Changhua 50074, Taiwan \\ * Correspondence: yswang@cc.ncue.edu.tw
}

Citation: Chen, I.Y.L.; Wang, Y.-S.; Li,

B.-R. Investigating the Relative

Performance of Bricks-and-Mortar, Clicks-and-Mortar, and Pure-Click Firms in Taiwan. Sustainability 2021, 13, 3516. https://doi.org/10.3390/ su13063516

Academic Editor:

Inma Rodríguez-Ardura

Received: 3 February 2021

Accepted: 18 March 2021

Published: 22 March 2021

Publisher's Note: MDPI stays neutral with regard to jurisdictional claims in published maps and institutional affiliations.

Copyright: (c) 2021 by the authors. Licensee MDPI, Basel, Switzerland. This article is an open access article distributed under the terms and conditions of the Creative Commons Attribution (CC BY) license (https:/ / creativecommons.org/licenses/by/ $4.0 /)$.

\begin{abstract}
The study compares the relative performance among bricks-and-mortar, clicks-and-mortar, and pure-click firms. The research model was tested in the Taiwan service industry using a Taiwan Economic Journal dataset of 1448 firms. Using regression analysis, the study provides empirical evidence that clicks-and-mortar firms outperform pure-click firms in terms of efficiency, but not better in profitability and even worse in efficiency than bricks-and-mortar firms. Pure-click firms need to improve their accounts receivable turnover ratio and total assets turnover. While the findings are not in full congruence with past studies, we provide theoretical explanations. Based on the findings, a strategic guide on going clicks and mortar is provided to practitioners.
\end{abstract}

Keywords: bricks and mortar; clicks and mortar; pure click; financial ratio analysis perspective; multichannel strategy

\section{Introduction}

The accelerating evolution of technology and the trend of digitalization have resulted in consumers being able to interact with firms across multiple channels including offline (e.g., physical stores) and online (e.g., Internet, social media, mobile phones, and tablets) [1] This has motivated firms to adopt a multichannel strategy and integrate offline and online channels to create a seamless shopping experience for consumers. Western retailers such as Carrefour and Wal-Mart have advanced information technologies to do business using a new retail approach [2]. The new retail format has influenced Asia Pacific countries such as Korean, China, and Taiwan firms and caused increased competition $[3,4]$. The digital transformation proceeds rapidly in the Chinese and Taiwanese retail industry, where online and offline business instantly merged [4]. Leading pure-click firms such as Amazon and Alibaba have added offline channel physical stores (i.e., Amazon's Amazon Go and Alibaba's Hema supermarket) to their existing online channels, and thereby transformed into clicks-and-mortar firms [5,6]. For both these firms, the online and offline channels are closely integrated by digital technologies. For instance, consumers can check in to the physical store through a mobile application that automatically tracks which items they choose, and then deducts payment after they exit the store [5].

Considerable e-commerce studies have examined the impact of marketing channels on the sustainability of e-business. For example, Chen and Zhang [7] explored how ecommerce influences sales growth of small and medium-sized enterprises in the shortand long-term. They found that what competitive advantage can be achieved largely depends on whether enterprises will effectively use the network technology. Chun [8] pointed out that the allocation of liability for security breaches is very important for the sustainability of e-businesses. Goersch [9] indicated that many of the multichannel retailers have recognized that multichannel integration can improve their customer acquisition and retention capabilities, which are crucial to the sustainability of all business firms. He 
contended that Web sites should facilitate and support consumers in their interaction with retailers throughout their purchase and consumption activities, regardless of in which channel the actual transaction takes place. His study elaborated on how multichannel integration can lead to benefits for consumers and retailers. He found that multichannel integration can also lead to cost savings for retailers.

While e-tailers (pure-click) have been moving into physical infrastructure construction, traditional retailers (i.e., bricks-and-mortar) have been moving into the online world $[10,11]$ by adding online channels. To capitalize on China's US\$103 billion jewelry market, Cartier, a western luxury brand, used WeChat as an electronic commerce platform to connect with Chinese consumers and promote sales [12]. Although the move from either bricks-andmortar or pure-click firms to clicks-and-mortar firms can create growth opportunities, it can also generate challenges [11]. As such, it is important to examine which type of firm (bricks and mortar, pure click, or clicks and mortar) produces the highest firm performance.

Most prior studies in this area have focused on customer-level outcomes such as purchase intention [13-16], channel choice behavior [17], and service adoption behavior [1]. However, relatively few studies have investigated firm-level outcomes, and those that did have inconclusive findings. Myung and Narcyz [18] divided the channel type into three types (i.e., bricks-and-mortar, clicks-and-mortar, and pure-click) and compared their financial performance. They found that clicks-and-mortar firms achieve significantly higher profitability than bricks-and-mortar andpure-click firms. While Pauwels and Neslin [19] and $\mathrm{Du}$ [20] indicated that clicks-and-mortar firms generate higher firm performance than either pure-click or bricks-and-mortar firms, Bernstein, Song and Zheng [21] indicated that this is not necessarily the case. Since the existing literature is limited and remains inconclusive, this issue calls for further investigation.

Network externality is a concept originally developed in economics and means that the gains that a group receives from adopting a product or service depend on the group's size [22]. Network externality theory has been applied in many electronic commerce studies. For example, Lin and Lu [23] applied network externalities and motivation theory to explain why people continue to join social network sites (SNS). Based on the analysis of data collected via online questionnaire, they found that enjoyment is the most influential factor in people's continued use of SNS, followed by number of peers, and usefulness. The number of peers and perceived complementarity have stronger impact than the number of members on perceived usefulness and enjoyment. As bricks-and-mortar firms, pure-click firms and clicks-and-mortar firms possess different network sizes, this study uses network externality as the theory base to develop the research hypotheses.

The aim of this study is to compare the relative firm performance among clicks-andmortar, bricks-and-mortar, and pure-click firms. The findings contribute to the channel integration literature as follows. First, this study simultaneously compares the relative firm performance among clicks-and-mortar, bricks-and-mortar, and pure-click firms to gain a more complete picture regarding which is the best option. Past studies have focused on comparisons either between clicks-and-mortar and pure-click firms [19] or between clicks-and-mortar and bricks-and-mortar firms [20,21]. Second, this study assesses firm performance from the perspective of financial ratio analysis, and both the profitability and efficiency (activity) ratios are included [24]. Past studies have focused on profitability measures [19-21,25], but ignored efficiency measures. Some of the financial ratio analysis literature indicates that both profitability and efficiency are important facets of firm performance $[26,27]$; as such, both measures should be considered when assessing firm performance. By adopting a financial ratio analysis perspective, this study captures firm performance in a more comprehensive manner. We found that clicks-and-mortar firms perform better than pure-click firms both in profitability and efficiency. However, clicksand-mortar firms fail to surpass bricks-and-mortar firms in terms of profitability, and even fall behind these firm types in terms of efficiency. Our findings are not in full congruence with those obtained in past studies; we provide theoretical explanations for these inconsistencies. Furthermore, based on our findings, we provide a strategic guide for 
practitioners who intend to move from either bricks-and-mortar firms or pure-click firms to clicks-and-mortar firms.

The remainder of this paper is organized as follows. The next section presents a review of the relevant literature, followed by hypotheses development. We then describe the research method, followed by thetest resultsof the hypotheses. Finally, we discuss the theoretical and practical implications, and conclude by presenting the limitations of this study, as well as suggestions for future areas of study.

\section{Literature Review}

\subsection{Bricks and Mortar, Pure Click, and Clicks and Mortar}

Bricks and mortar is a channel type associated with traditional retailers. Firms that use bricks and mortar possess a traditional building or store to offer products/services without using the Internet [21,28]. These firms rely on face-to-face contact with their customers via physical locations [10]. The physical presence of a firm allows consumers to visit the store, where they can touch and feel products before making a purchase [11,29] (p. 137).

With the widespread commercial usage of Internet, many online retailers (e-tailers) have adopted the pure-click channel type [10]: business transactions are exclusively carried out in electronic online markets $[30,31]$. These firms interact with consumers solely through the Internet without face-to-face contact [10]. Consumers can access online information about products, place an order, pay, and have them delivered. Logistics activities such as warehousing, goods shipment, and delivery are often outsourced to subcontractors.

Compared to pure-click firms, bricks-and-mortar firms have the physical presence of a store, which gives consumers a sense of security and trust [10]. Most importantly, bricks-and-mortar firms offer consumers the physical shopping experience. In addition to being able to touch, feel, and try products; they can obtain personal face-to-face advice from staff [10]. However, compared with pure-click firms, bricks-and-mortar firms have limited operating hours and days, and require high investments in terms of physical infrastructure [10]. Moreover, pure-click firms offer advantages such as wide reach, exhaustive product selection, few infrastructure requirements, unlimited operating hours, and a high degree of scalability over bricks-and-mortar firms [10]. However, pure-click firms have difficulty building a trust with consumers due to the lack of physical presence. Furthermore, the physical shopping experience cannot be provided [10].

As discussed above, both bricks-and-mortar and pure-click firms have advantages and disadvantages; in an effort to capitalize on the former, many firms of both types have chosen to switch to clicks and mortar [10]. Clicks and mortar refers to a channel type that combines bricks and mortar and pure click, in that firms use both physical stores and the Internet for operations [21]. As such, customers can use the Internet to shop, but they are also able to physically visit a bricks-and-mortar store [28].

Moving to clicks and mortar provides many benefits to consumers and firms. Consumers can browse and search for products more conveniently, and can opt for delivery or pick-up of their purchases. Consumers can cross online and offline freely. Specifically, they can search for product information at physical stores but make purchases at a lower price using online channels [32]. Well-known bricks-and-mortar firms can establish trust in the online world easily [10]. However, transforming to clicks and mortar often requires organizational restructuring, adapting the existing distribution infrastructure to the requirements of the online market, and altering training to focus on essential skills and competencies concerning the cyber venture [10]. For pure-click firms, moving to clicks and mortar also brings benefits and challenges. The addition of the physical channel provides consumers with a physical shopping experience and serves as a powerful advertising medium to enhance online sales. However, since pure-click firms frequently outsource their logistics activities, they may struggle with the complexity of integrating multiple suppliers in a seamless manner to meet consumers' expectations [10]. 


\subsection{Channel Integration}

The development of e-commerce and new digital channels has led retailers to interact with consumers across multiple channels, such as websites, physical stores, catalogs, mobile applications, and social media [1]. The existing literature uses different terms to describe this, including multichannel retailing and omnichannel retailing. The former refers to the use of different channels to contact and satisfy the needs of different types of consumers [33]. In multichannel retailing, each channel operates separately and has its own logistics system [16]. On the other hand, the latter aims to create a seamless and complete shopping process and customer experience for consumers [34] through the establishment of an integrated operation system including logistics and after sale service support [33].

Although multichannel retailing and omnichannel retailing both use multiple channels, they differ in terms of the level of cross-channel integration, which refers to the extent to which firms coordinate the objectives, design, and deployment of their channels to create synergies for themselves that offer particular benefits to consumers [25]. Multichannel retailing has a low level of cross-channel integration, while omnichannel retailing has a high level. With the increasing diversity of channels (e.g., mobile, tablets, and social media), transferring from multichannel retailing to omnichannel retailing is a priority issue for many retailers [34], and the importance of successful channel integration is clear.

Numerous studies have been conducted on different types of channel integration with respect to price, assortment, inventory, order-fulfillment, service, online-offline and offlineonline [16]. The rise of online enterprises has resulted in increased attention being paid to multichannel management, especially for channel relationships between online and offline channels [20,35,36]. Wu and $\mathrm{Wu}$ [37] presented a complete implementation model for effectively directing channel integration between virtual and physical channels for internet businesses. As such, present research focuses on channel integration for clicks-and-mortar firms or firms that use both online and offline channels for business operation.

\subsection{Channel Integration for Clicks-and-Mortar Firms}

Channel integration for clicks-and-mortar firms can be divided into offline-online channel integration and offline-online channel integration. The former refers to providing access to and knowledge about the online store at physical stores, while the latter is defined as providing access to and knowledge about the physical store through online stores [11]. Past studies have focused on the positive effects associated with both types of channel integration: for offline-online channel integration, self-service online terminals and information on online channels can diminish the negative impact of inventory non-availability in offline stores [38], assisted online terminals can complement offline personal service [39], and online banking terminals in the branch environment can create a better service experience [40]. For offline-online channel integration, retailers can offer information on offline store locations or inventory through online stores to reduce consumers' perceived risk regarding the online stores [11].

Most prior studies have indicated that channel integration (i.e., online and offline channels) can facilitate consumer perceived outcomes such as purchase intention [13-16], channel choice behavior [17], and service adoption behavior [1]. Drawing from the technology acceptance model (TAM), Berg and Tornblad [13] revealed that perceived security and perceived usefulness are the key drivers of purchase intention. Based on unified theory of acceptance and use of technology 2 (UTAUT2), Juaneda-Ayensa et al. [14] indicated that personal innovativeness, effort expectancy, and performance expectancy are key antecedents of purchase intention. Yurova et al. [15] adopted the perspective of salespeople's adaptive selling behavior and indicated that non-interactive adaptive selling behaviors, consumers' perceived control, and initial purchase intention facilitate consumers' purchase intention, while interactive adaptive selling behaviors have a greater effect on purchase intention for hedonic products than utilitarian products. Park and Lee [17] indicated that communication strategies such as SMS and app push notifications significantly influence consumer channel choice. 
Past studies also revealed the mechanism from offline-online channel integration to consumer-level outcomes from different perspectives. From the perspective of technology adoption and diffusion, offline-online channel integration can directly increase perceived service quality of the online store, which in turn increases overall channel outcomes and Internet channel outcomes. Furthermore, offline-online channel integration does not negatively influence physical store outcomes [11]. From the perspective of consumer empowerment, offline-online channel integration can promote consumer empowerment, resulting in enhanced trust and satisfaction and improved consumer patronage intention [16].

While most prior studies have focused on consumer perceived outcomes, relatively few have examined firm-level outcomes [20]. Pauwels and Neslin [19] indicated that the addition of an offline store had a less negative impact (i.e., cannibalization) on the sales of Internet stores, and produced a net increase in purchase frequency across channels, which resulted in higher overall sales. Du [20] noted that when credit union channel diversity increased from physical channels to both physical and online channels, profitability increased while profit volatility decreased. However, Bernstein et al. [21] indicated that compared to bricks and mortar, clicks and mortar does not necessarily enhance firm profit. Specifically, when consumers value the product highly or are not very price sensitive toward it, the addition of an Internet channel does not lead to additional value (profit). In contrast, when consumers have an outside option (not purchasing the product from any firm), all firms benefit from establishing online channels. These studies are inconclusive concerning whether clicks-and-mortar firms perform better than pure-click or bricks-and-mortar firms in terms of firm-level outcomes, which deserves further examination. Furthermore, these studies have focused on the comparison of firm performance, either between clicks-and-mortar and pure-click firms [19], or clicks-and-mortar and bricks-and-mortar firms [20,21]. The current study simultaneously compares the relative performance among clicks-and-mortar, bricks-and-mortar, and pure-click firms in terms of firm-level outcomes to gain a more complete picture regarding which is the best option.

\subsection{Network Externality Theory}

Katz and Shapiro [22] defined network externalities as "the value or effect that users obtain from a product or service will bring about more values to consumers with the increase of users, complementary product, or service."Two types of network externalities exist: direct and indirect effects. The direct effect of network externalities is that the gains from adopting a product or service increase depending on the increase in the size of the population using that product or service [22]. Indirect network effects mean that one group's gains depend on the size of the other groups that exist on the same platform, and this works for every other group [41,42].

Network externality theory has been used in many studies of electronic commerce or social marketing. Zhang, Tsai, Lin, Cheng, and Lu [43] proposed a conceptual model that articulated the relationships among different degrees of knowledge gap, platform quality, and risk management in predicting the various combinative losses in the economic, social, and psychological aspects. Based on the assumption of network externality, they argued that the multiple dimensions of fraud-caused losses may damage e-auction sustainability.

Yang and Mai [44] used online users' reviews and sales information from May 2003 to March 2007 to study a new experiential product: online video game. They found that negative word-of-mouth had a more significant impact than positive reviews. Their study empirically verified that the existence of direct network externalities is crucial for a hedonic product. The size of the user base signals the quality of the game, and works like a search attribute for potential users. A large user base will reduce the negative impact from unfavorable reviews.

\section{Hypothesis Development}

The network externality theory postulates that the size of a user network can increase its strength. A strong user network enhances a product's value, which in turn attracts 
resources and facilitates the likelihood of purchase [22,45]. Bricks-and-mortar firms own physical channel networks, pure-click firms possess Internet channel networks, and clicksand-mortar firms have both physical and Internet channel networks. Based on the theory, compared to either bricks-and-mortar or pure-click firms, clicks-and-mortar firms are greater in (channel) network size, leading consumers to infer that clicks-and-mortar firms offer products of greater value, and they can obtain greater resources from clicks-andmortar firms (those from both bricks-and-mortar and pure-click firms such as face-to-face support from staff, easy access to online product information), which in turn facilitates increased purchase behavior from clicks-and-mortar firms.

Furthermore, the combination of online and offline channels for clicks-and-mortar firms allows these firms to offer value-added services to consumers, who often respond by concentrating their purchases in the same firms [25]. Based on the above, clicks-andmortar firms can enjoy greater profitability than either bricks-and-mortar or pure-click firms. Hence, the following hypothesis is posited:

Hypothesis 1 (H1). Compared to either bricks-and-mortar or pure-click platforms, firms with clicks-and-mortar platforms are more profitable.

The network externality theory also postulates that increased network accessibility (verbally, visually, or electronically) leads to increased network influence on potential adopters $[46,47]$. Compared to either bricks-and-mortar or pure-click firms, clicks-andmortar firms are more accessible for consumers, facilitating increased contact with consumers [48,49] in their preferred channel [9], which in turn increases transaction efficiency. For instance, consumers can easily make payments using different channels, which decreases the likelihood that they delay due to channel inconvenience. The choice of different channels can also strengthen consumers' sense of self-control and security [9], leading to increased firm trust [25]. The combination of channels can encourage consumers to develop long-term relationships and relationship commitment (loyalty) with clicks-and-mortar firms by providing value-added services and customization $[25,49,50]$.

The establishment of both trust and relationship commitment can generate outcomes that promote efficiency and productivity [51]. Furthermore, the combination of online and offline channels for clicks-and-mortar firms allows firms to transfer consumers from one channel to another $[48,49]$ as needed. The marketing efforts in one channel can also increase the sales associated with another channel, which also increases efficiency. Finally, channel integration can increase consumer data sharing across channels and lead to a more complete customer profile [52,53], thereby facilitating transactional efficiency. Based on the above, we propose the following:

Hypothesis 2 (H2). Compared to either bricks-and-mortar or pure-click platforms, firms with clicks-and-mortar platforms generate greater efficiency.

\section{Methods}

\subsection{Sample}

This study collected financial data pertaining to the stock exchange and over-thecounter market for the years 2005 to 2014 of listed service industry firms from the Taiwan Economic Journal (TEJ) database. This database is authoritative, and is frequently used by both academics and practitioners in Taiwan [54]. This study analyzed the 2005-2014 period, as prior studies have used this period to analyze the financial performance of firms in this developing economy [55]. The rapid technological development of online service in this period [56] corresponds to the channel platforms (i.e., pure-click and clicks-and-mortar platforms) examined in this study.

Moreover, according to the E-commerce Development and Promotion Policy Report of the Ministry of Economic Affairs Department of Commerce [57], the government regulations in Taiwan for the emerging business model of the Sharing Economy, as well as 
the business tax law for cross-border e-commerce, became effective from 2016, supporting online merchants with affiliate marketing platforms, and supporting the service industry in expanding cross-border e-commerce business. These regulations are not applicable to bricksandmortar. This has encouraged increasing clicks-and-mortar and pure-click firms to affiliate with e-commerce platforms (e.g., PChome, Shopee). Many of these online merchants have benefited from the affiliation strategy and have gained improved financial performance since then. Given that the effect of affiliation strategy may bias the result of comparison among clicks-and-mortar, pure-click and bricks-and-mortar firms in terms of profitability and efficiency, this study analyzed the 2005-2014 period.

This study focused on the service industry, since it is the main type of economic activity in Taiwan. According to statistics released by the National Development Council, the service industry in Taiwan accounted for $63.15 \%$ of the gross domestic product (GDP) and $59.17 \%$ of total employment in 2016 [58]. The service industry includes retail, information services, electronic products, transportation, tourism, and cultural and creative industries. Stratified random sampling was used to collect 1776 data of firms based on the population proportion in the service industry. We spread the sample across different industries with similar proportions to avoid drawing too much or too little of each layer, and to reduce sampling errors. After deleting inappropriate and incomplete firm data, 1448 remained. Of these, $20.2 \%$ belonged to the information services industry, $20.0 \%$ to the electronic product industry, $16.9 \%$ to the retail industry, $16.4 \%$ to transportation, $14.9 \%$ to tourism, and $11.5 \%$ to the cultural and creative industry.

\subsection{Independent Variable and Measurement}

The independent variable in this study was the three types of channel platforms: bricks and mortar, pure click, and clicks and mortar. Since channel platform type was a categorical variable with three levels, two dummy variables were created. Reference coding was used when the clicks-and-mortar group was the baseline. For the clicks-andmortar group, Dummy 1 and Dummy 2 were equal to 0 . The bricks-and-mortar group was represented when Dummy 1 was equal to 1 and Dummy 2 equal to 0 . The pure-click group was represented when Dummy 1 was equal to 0 and Dummy 2 equal to 1.

\subsection{Dependent Variables and Measurement}

The key dependent variable in this study was firm performance, assessed from the perspective of financial ratio analyses. Among the different types of financial ratios, this study focused on profitability and efficiency (activity) ratios, since they are the focus of industrial organizations [26] and are significant predictors for the years immediately prior to the failure of a company [27].

\subsubsection{Profitability}

Return on assets (ROA), return on equity (ROE), and return on sales (ROS) are accounting-based measures to assess current profitability of a firm [59,60]. ROA is computed by dividing net income before tax by the book value of total assets [59,61] and reflects a firm's performance in using assets to create net income independent of how these assets are financed [62] (p. 223). ROE is equal to net income before tax divided by shareholders equity [59], which indicates a firm's performance in using the resources provided by the shareholders to create net income [62] (p. 222). ROE differs from ROA in that it measures profitability based on a specific source of financing (the portion provided by shareholders) [62] (p. 223). ROS is counted as a firm's pretax profit divided by total sales [63], which measures a firm's profit per dollar of sales [64].

\subsubsection{Efficiency}

The efficiency of a firm is assessed using the accounts receivable turnover ratio (ARTurnover) and the total assets turnover (TATurnover). ARTurnover is calculated by dividing net credit sales by the average accounts receivable. This ratio reflects how many times a 
firm's accounts receivable is generated and collected during the year. High ARTurnover indicates that a firm manages its accounts receivable efficiently [65] (p. 56). TATurnover is computed by dividing net sales by average total assets, and reflects the efficiency with which management uses assets to generate sales [66].

\subsection{Control Variables and Measurement}

\subsubsection{Firm Size}

The size of the firm can influence firm performance [67]. Previous research has indicated that firm size plays a vital role in explaining market returns [68,69] and efficiency [70]. Since the distribution of firm size is positively skewed, the natural logarithm of total assets was used to measure firm size $[67,69,71]$. Alternatively, the number of employees can be used to measure firm size [61,72]. Following Richard and Johnson [73], the current study used both the natural logarithm of total assets (SIZE_TA) and number of employees (SIZE_EMP) to operationalize firm size.

\subsubsection{Leverage}

Corporate governance theory predicts that leverage (debt ratio) influences agency costs and thereby affects firm performance $[69,74]$. Leverage is correlated negatively with firm performance [71,75]. The leverage (LEV) is calculated as the book value of total debt divided by the book value of total capital [71], reflecting the degree to which the assets of a firm come from debt.

\subsubsection{Firm Age}

The age of a firm affects financial performance since firm age captures differences in firm competitiveness associated with history [69]. Firm age is positively related to agent conflicts, which in turn influences firm performance [76]. Firm age has either positive or negative effect on efficiency [70]. Similar to Wang et al. [69], firm age (AGE) was calculated as the number of years since the firm's first listing in the TEJ.

\section{Results}

\subsection{Descriptive Statistics}

The results of the descriptive statistics are summarized in Table 1 . The mean value of firm size measures for the total sample was greater than that for both bricks-and-mortar and pure-click firms, but smaller than that for clicks-and-mortar firms. The mean value of firm debt ratio (LEV) for the total sample was greater than that for pure-click firms, equal to that for clicks-and-mortar firms, and smaller than that for bricks-and-mortar firms. Compared to the total sample, bricks-and-mortar and clicks-and-mortar firms were both relatively old in terms of firm age as compared to pure-click firms.

The mean values of all profitability measures for clicks-and-mortar firms were greater than that for the total sample. Bricks-and-mortar firms had higher ROS but lower ROA and ROE compared to the total sample, while pure-click firms had higher ROA but lower ROE and ROS than the total sample. As for measures of efficiency, compared to the total sample, bricks-and-mortar firms had higher ARTurnover and TATurnover, and clicks-and-mortar firms had higher TATurnover but equal ARTurnover, while pure-click firms performed poorly on both ARTurnover and TATurnover. 
Table 1. Descriptive statistics for three types of channel strategy.

\begin{tabular}{ccccccccc}
\hline & \multicolumn{2}{c}{$\begin{array}{c}\text { Bricks and Mortar } \\
(\boldsymbol{n}=\mathbf{6 4 5 )}\end{array}$} & \multicolumn{2}{c}{ Pure Click $(\boldsymbol{n}=\mathbf{2 2 3})$} & \multicolumn{2}{c}{$\begin{array}{c}\text { Clicks and Mortar } \\
(\boldsymbol{n}=\mathbf{5 8 0})\end{array}$} & Total $(\boldsymbol{n = 1 4 4 8 )}$ \\
& Mean & S.D. & Mean & S.D. & Mean & S.D. & Mean & S.D. \\
\hline SIZE_TA & 14.94 & 1.30 & 14.23 & 1.15 & 15.39 & 1.73 & 15.11 & 1.51 \\
SIZE_EMP & 958.20 & 1686.18 & 619.77 & 703.147 & 2612.99 & 5195.03 & 1568.91 & 3589.20 \\
LEV & 0.47 & 0.18 & 0.34 & 0.19 & 0.44 & 0.18 & 0.44 & 0.19 \\
AGE & 24.53 & 12.59 & 15.57 & 7.37 & 27.86 & 14.18 & 24.48 & 13.27 \\
ROA & 8.65 & 9.64 & 12.65 & 15.94 & 10.33 & 9.08 & 9.94 & 10.74 \\
ROE & 8.77 & 15.98 & 8.31 & 24.79 & 9.04 & 15.87 & 8.81 & 17.57 \\
ROS & 6.81 & 14.47 & 5.14 & 23.04 & 6.78 & 14.09 & 6.54 & 15.95 \\
ARTurnover & 1.53 & 1.26 & 1.00 & 0.78 & 1.40 & 1.26 & 1.40 & 1.21 \\
TATurnover & 33.09 & 70.34 & 13.33 & 19.07 & 29.00 & 44.04 & 28.41 & 55.49 \\
\hline
\end{tabular}

SIZE_TA stands for firm size measured as the natural logarithm of total assets, SIZE_EMP for firm size measured as the number of employees, LEV for leverage, AGE for organization age, ROA for return onassets, ROE for return on equity, ROS for return on sales, ARTurnover for accounts receivable turnoverratio and TATurnover for total assets turnover.

\subsection{Regression Analyses}

Five regression models were estimated to examine whether channel type influenced ROA (model 1), ROE (model 2), ROS (model 3), ARTurnover (model 4), and TATurnover (model 5), respectively, controlling for SIZE_TA, SIZE_EMP, LEV, and AGE. Dummy variables herein help to show the impact of each company group. The results for the five regression models are shown in Table 2. The variance inflation factor (VIF) values on all independent variables were between 1.26 and 2.00 , indicating that multicollinearity was not a severe problem.

Table 2. Results of regression analysis.

\begin{tabular}{|c|c|c|c|c|c|}
\hline Variables & $\begin{array}{l}\text { Model } 1 \\
\text { DV: ROA }\end{array}$ & $\begin{array}{l}\text { Model } 2 \\
\text { DV: ROE }\end{array}$ & $\begin{array}{l}\text { Model } 3 \\
\text { DV: ROS }\end{array}$ & $\begin{array}{c}\text { Model } 4 \\
\text { DV: ARTurnover }\end{array}$ & $\begin{array}{c}\text { Model } 5 \\
\text { DV: TATurnover }\end{array}$ \\
\hline & $b$ & $b$ & $b$ & $b$ & $b$ \\
\hline \multicolumn{6}{|l|}{ Control } \\
\hline SIZE_TA & $0.87^{* * *}$ & $2.24^{* * *}$ & $2.97 * * *$ & $-0.05 *$ & $4.18^{* *}$ \\
\hline SIZE_EMP & 0.00 & 0.00 & 0.00 & 0.00 & 0.001 \\
\hline LEV & $-14.66^{* * *}$ & $-19.21 * * *$ & $-32.01^{* * *}$ & $2.41^{* * *}$ & -11.38 \\
\hline $\begin{array}{l}\text { AGE } \\
\text { IV }\end{array}$ & $-0.19^{* * *}$ & $-0.29^{* * *}$ & -0.05 & $-0.03^{* * *}$ & -0.08 \\
\hline $\begin{array}{c}\text { Dummy } 1 \\
\text { (Bricks and mortar) }\end{array}$ & -1.03 & 0.73 & 1.41 & -0.05 & $7.07^{*}$ \\
\hline $\begin{array}{c}\text { Dummy } 2 \\
\text { (Pure click) }\end{array}$ & 0.05 & $-3.10 *$ & $-2.88^{*}$ & $-0.55^{* * *}$ & $-11.67^{*}$ \\
\hline \multicolumn{6}{|l|}{ Model summary } \\
\hline R2adj & 0.09 & 0.05 & 0.12 & 0.25 & 0.025 \\
\hline F & 25.35 & 14.32 & 34.61 & 81.24 & 7.13 \\
\hline
\end{tabular}

$n=1448$; DV stands for dependent variable, IV for independent variable, Control for control variables, $\mathrm{b}$ for unstandardized regression coefficient, SIZE_TA stands for firm size measured as the natural logarithm of total assets, SIZE_EMP for firm size measured as the number of employee, LEV for leverage, AGE for organization age, ROA for return on assets, ROE for return on equity, ROS for return on sales, ARTurnover for accounts receivable turnover ratio and TATurnover for total assets turnover; ${ }^{* * *} p<0.001,{ }^{* *} p<0.01,{ }^{*} p<0.05$.

\subsubsection{Profitability}

For model 1, SIZE_TA, LEV, and AGE functioned as effective control variables because these all significantly influenced ROA. Both Dummy $1(b=-1.03, p>0.05)$ and Dummy 2 $(b=-0.05, p>0.95)$ had insignificant effects on ROA, indicating that clicks-and-mortar firms failed to produce higher ROA than either bricks-and-mortar or pure-click firms.

For model 2, SIZE_TA, LEV, and AGE functioned as effective control variables because these all significantly influenced ROE. The effect of dummy 1 on ROE was not significant 
$(b=0.73, p>0.47)$, indicating that clicks-and-mortar firms failed to generate higher ROE than bricks-and-mortar firms. Dummy 2 had a significant and negative effect on ROE $(b=-3.10, p<0.05)$, indicating that clicks-and-mortar firms had higher ROE than pureclick firms.

For model 3, SIZE_TA and LEV functioned as effective control variables because these all significantly influenced ROS. The effect of dummy 1 on ROS was not significant $(b=1.41, p>0.11)$, indicating that clicks-and-mortar firms did not achieve higher ROS than bricks-and-mortar firms. Dummy 2 had a significant and negative effect on ROS $(b=-2.88$, $p<0.05)$, indicating that clicks-and-mortar firms had higher ROS than pure-click firms.

Taken together, the results reveal that clicks-and-mortar firms had higher profitability than pure-click firms since the former performed better than the latter on two of the three profitability measures (i.e., ROE and ROS). However, clicks-and-mortar firms did not generate higher profitability than bricks-and-mortar firms. Hence, $\mathrm{H} 1$ is partially supported.

\subsubsection{Efficiency}

For model 4, SIZE_TA, LEV, and AGE functioned as effective control variables because these all significantly influenced ARTurnover. The effect of dummy 1 on ARTurnover was not significant $(b=-0.05, p>0.44)$, indicating that clicks-and-mortar firms did not result in higher ARTurnover than bricks-and-mortar firms. Dummy 2 had a significant and negative effect on ARTurnover $(b=-0.55, p<0.001)$, indicating that clicks-and-mortar firms had higher ARTurnover than pure-click firms.

For model 5, SIZE_TA functioned as an effective control variable because it significantly influenced TATurnover. The effect of dummy 1 on TATurnover was significant and positive $(b=7.07, p<0.05)$. This indicates that bricks-and-mortar firms experienced higher TATurnover than clicks-and-mortar firms. Dummy 2 had a significant and negative effect on TATurnover $(b=-11.67, p<0.05)$, indicating that clicks-and-mortars firms had higher TATurnover than pure-click firms.

In sum, the results denote that clicks-and-mortar firms had higher efficiency than pure-click firms since the former performed better than the latter on the measures reflecting efficiency (i.e., ARTurnover and TATurnover). However, the results contrast with our expectations regarding this comparison. Specifically, compared with bricks-and-mortar firms, clicks-and-mortar firms did not generate higher ARTurnover but did experience lower TATurnover. These results partially support $\mathrm{H} 2$.

\subsection{Robustness Check}

Since the sample sizes for the three groups (i.e., bricks-and-mortar, pure-click, and clicks-and-mortar firms) are not equal, a robustness check was used to test the stability of the research findings. A random sample of 200 was drawn from each group and the same regression analysis was conducted.

As shown in Table 3, the results regarding the effects of key independent variables (i.e., Dummy 1 and Dummy 2) on dependent variables were mostly consistent with the findings of the formal regression analysis. However, the effect of dummy 2 on TATurnover was not significant. This can be attributed to the reduction in statistical power resulting from the decrease of the sample size from 1448 to 600. Although the effect of dummy 2 on TATurnover was not significant, the regression coefficient was negative and consistent with the findings of the formal regression analysis. 
Table 3. Robustness check.

\begin{tabular}{|c|c|c|c|c|c|c|c|c|c|c|}
\hline \multirow[t]{2}{*}{ Variables } & \multicolumn{2}{|c|}{$\begin{array}{c}\text { Model } 1 \\
\text { DV: ROA }\end{array}$} & \multicolumn{2}{|c|}{$\begin{array}{l}\text { Model } 2 \\
\text { DV: ROE }\end{array}$} & \multicolumn{2}{|c|}{$\begin{array}{l}\text { Model } 3 \\
\text { DV: ROS }\end{array}$} & \multicolumn{2}{|c|}{$\begin{array}{c}\text { Model } 4 \\
\text { DV: ARTurnover }\end{array}$} & \multicolumn{2}{|c|}{$\begin{array}{c}\text { Model } 5 \\
\text { DV: TATurnover }\end{array}$} \\
\hline & $b$ Sign & $p$ & $b$ Sign & $p$ & $b$ Sign & $p$ & $b$ Sign & $p$ & $b$ Sign & $p$ \\
\hline \multicolumn{11}{|l|}{ Control } \\
\hline SIZE_TA & + & 0.235 & + & 0.015 & + & 0.000 & - & 0.331 & + & 0.002 \\
\hline SIZE_EMP & + & 0.005 & + & 0.103 & - & 0.048 & - & 0.836 & - & 0.245 \\
\hline LEV & - & 0.000 & - & 0.000 & - & 0.000 & + & 0.000 & + & 0.946 \\
\hline AGE & - & 0.000 & - & 0.000 & - & 0.298 & - & 0.000 & - & 0.273 \\
\hline \multicolumn{11}{|l|}{ IV } \\
\hline $\begin{array}{c}\text { Dummy } 1 \\
\text { (Bricks and } \\
\text { mortar) }\end{array}$ & - & 0.219 & - & 0.549 & + & 0.888 & - & 0.219 & + & 0.039 \\
\hline $\begin{array}{c}\text { Dummy } 2 \\
\text { (Pure click) }\end{array}$ & - & 0.813 & - & 0.014 & - & 0.011 & - & 0.000 & - & 0.158 \\
\hline \multicolumn{11}{|c|}{ Model summary } \\
\hline R2adj & \multicolumn{2}{|c|}{0.08} & \multicolumn{2}{|c|}{0.05} & \multicolumn{2}{|c|}{0.11} & \multicolumn{2}{|c|}{0.24} & \multicolumn{2}{|c|}{0.06} \\
\hline $\mathrm{F}$ & \multicolumn{2}{|c|}{10.08} & \multicolumn{2}{|c|}{6.43} & \multicolumn{2}{|c|}{13.42} & \multicolumn{2}{|c|}{32.45} & \multicolumn{2}{|c|}{7.50} \\
\hline
\end{tabular}

$n=600$; DV stands for dependent variable, IV for independent variable, Control for control variables, $\mathrm{b}$ sign for the sign of unstandardized regression coefficient, $p$ for $p$-value, SIZE_TA for firm size measured as the natural logarithm of total assets, SIZE_EMP for firm size measured as the number of employee, LEV for leverage, AGE for organization age, ROA for return on assets, ROE for return on equity, ROS for return on sales, ARTurnover for accounts receivable turnover ratio and TATurnover for total assets turnover.

\section{Discussion}

Many pure-click firms have sprung up due to ongoing digitalization. The resulting increase in retail competition has seen bricks-and-mortar firms add online channels and pure-click firms incorporate offline channels [34]. Since many firms have adopted a multichannel strategy focused on clicks and mortar [34], it is imperative to examine whether firms that follow this model can generate better performance than either bricks-and-mortar or pure-click firms. Past studies have indicated that the integration of different channels can be both performance enhancing (e.g., enriched customer value proposition [77], complementarity [11], and profitability [25]) and performance destroying (e.g., cannibalization [78], negative spill-over effects [79], and loss of market share and profits [21]). Since the findings of past studies have been inconclusive, this issue deserves additional examination. Furthermore, past studies have focused on either offline-online integration (from bricks and mortar to clicks and mortar) or offline-online integration (from pure click to clicks and mortar). The current study contributes to the multichannel strategy literature by simultaneously comparing the relative performance among bricks-and-mortar, pure-click, and clicks-and-mortar firms to gain a more complete picture. Moreover, most previous studies assessed firm performance using measures reflecting profitability (e.g., [19-21,25]). By adopting using financial ratio analyses, this study evaluates firm performance in a more comprehensive manner using financial ratios that measure both profitability and efficiency.

The findings of this study reveal that clicks-and-mortar firms are more profitable than pure-click firms, which corroborates Pauwels and Neslin's [19] notion that the addition of an offline store increases overall sales. Our results further indicate that clicks-and-mortar firms are more efficient than pure-click firms. However, we found that clicks-and-mortar firms are not as profitable or efficient as bricks-and-mortar firms. These findings are in contrast to those obtained by $\mathrm{Du}$ [20] and Bernstein et al. [21]: the former noted positive empirical evidence, and the latter provided a contingent answer, while the current empirical findings are negative. These inconsistent results can be attributed to the different scopes of comparison. Both previous studies compared only two channel strategy options: clicks and mortar and bricks and mortar. The current study adds the pure-click option. Compared to $\mathrm{Du}$ [20] and Bernstein et al. [21], the scope of comparison in our study is more complete, which can reduce the potential for bias resulting from a narrower scope of comparison. 


\subsection{Theoretical Implications}

This study is the first to apply the network externality theory $[22,45]$ to investigate relative performance among three channel platforms: bricks and mortar, clicks and mortar, and pure click. Based on this theory, we infer that since clicks-and-mortar firms have a larger network size and greater accessibility than either bricks-and-mortar or pure-click firms, clicks-and-mortar firms are more likely to attract consumers who in turn make purchases, leading to better firm performance. However, this theoretical prediction is only partially supported. Specifically, although clicks-and-mortar firms produced higher profitability and efficiency than pure-click firms, they failed to generate higher profitability and efficiency than bricks-and-mortar firms. These surprising results may be attributed to the different levels of complexity among the three channel platforms. Although clicksand-mortar firms have greater management complexities than both bricks-and-mortar and pure-click firms, the increase in complexity from bricks and mortar to clicks and mortar is greater than from pure click to clicks and mortar. Compared to bricks-and-mortar firms, clicks-and-mortar firms must deal with complexity issues resulting from the use of Internet channels. In today's digital age, there are numerous Internet channel options available to firms including websites, blogs, video blogs, online communities, social networking sites, and mobile applications, and integrating these greatly increases management complexity. Furthermore, the use of Internet channels allows consumers to shop online, which calls for different logistics tasks, again increasing management complexity [80]. For instance, most bricks-and-mortar firms have little or no home delivery experience, which is a basic requirement when serving an online market [80]. On the other hand, pure-click firms have significant experience handling online channels, which reduces management complexity for them as they transform into clicks-and-mortar firms. The current study contributes to the network externality theory by indicating that when applying the theory to multichannel or omnichannel retailing contexts, other than accessibility, the management complexity resulting from different channel types should be considered, since accessibility and management complexity may counterbalance each other.

Although Enders and Jelassi [10] indicated that many pure-click firms experience difficulty transforming into clicks-and-mortar firms, since the required physical infrastructure triggers problems associated with supplier integration, our findings reveal that clicks-and-mortar firms are more profitable and efficient. The advancement of digital technology can help firms to integrate suppliers in a seamless manner and create a seamless shopping experience for consumers. Furthermore, going clicks and mortar can cultivate an organization's dynamic capabilities, which in turn generates a competitive advantage. Specifically, bricks-and-mortar and pure-click management environments are both relatively straightforward as compared with clicks-and-mortar ones; by transforming to clicks and mortar, organizations can develop new capabilities to help them adapt to the more complex environment.

\subsection{Practical Implications}

Based on the research findings, this study provides a strategic guide for practitioners to move from being either bricks-and-mortar or pure-click firms to clicks-and-mortar firms. Although clicks and mortar is a trend, and can enhance firm performance and efficiency as compared to pure click; the same is not true for bricks and mortar, where our results show that the transformation fails to increase profitability and even decreases efficiency with respect to total assets. The management complexity resulting from the transformation into clicks and mortar is more pronounced for bricks-and-mortar firms than for pure-click firms. As such, when pursuing a clicks-and-mortar strategy, practitioners operating bricksand-mortar firms should devote greater resources to complexity management than those operating pure-click firms.

To handle the increased complexity resulting from the transformation process, practitioners can follow a strategic guide divided into a decision stage, preparation stage, implementation stage, and controlling stage. In the decision stage, practitioners decide 
whether to go clicks and mortar. As noted above, this decision is more pronounced and influential for bricks-and-mortar firms than for pure-click firms. Moreover, a bricksand-mortar firm's strong reputation is conducive to sales growth from its online channel following transformation into a clicks and mortar. In this stage, practitioners can seek out channel integration experts for advice to help them decide on the best course of action. The preparation stage includes three steps: take training courses to be familiar with the features and characteristics of different types of online and offline channels, the logistics systems, and payment platforms; recruit channel integration experts to help smooth the planning process for the integration of online and offline channels; and invest in facilities and technologies that help facilitate information sharing among offline and online channels. In the implementation stage, there are two recommended steps: experiment with different types of offline and online channels prior to the formal transformation and choose those with a higher probability of success; and ensure top management's support and willingness to lead by example throughout the implementation process. Finally, in the controlling stage, practitioners have to carefully monitor the profitability and efficiency measures of both online and offline channels to identify whether cannibalization or a negative spill-over effect is occurring, and if so, take corrective action immediately.

Once practitioners decide to go clicks and mortar, the preparation, implementation, and controlling stages should be iterative and closed intertwined. If there are issues during the latter stages, practitioners need to go back to the previous stages to identify problems and correct them. If practitioners find it difficult to correct these problems such that going clicks and mortar results in significant profit losses and lower efficiency (i.e., the benefits resulting from clicks and mortar surpassing the costs incurred), they may need to revert to the original channel option (i.e., pure click or bricks and mortar).

\section{Limitations and Future Studies}

Our study has the following limitations. First, the findings of this study pertain to the relative performance among bricks-and-mortar, clicks-and-mortar, and pure-click firms in the service industry context, and may not be generalizable to other industries. Future studies can test the research model across other industries. Second, the research model was tested in Taiwan. Investigating the role of distribution channels of supply chain management in Taiwan is relevant, as Taiwan has received US $\$ 39.08$ billion of investment pledges from global companies to transport parts of their production lines back to their home country [81]. The findings of this research have potential to be applied to countries in Southeast Asia, South Asia and Australasia under the Taiwanese President Tsai's New Southbound Policy, which intends to establish a supply chain system with emerging markets [81]. However, the findings of this research may not be generalizable to other countries in the world, and this deserves future investigation. Third, this study focused on the financial dimension of firm performance and used profitability and efficiency measures to assess firm performance. Since firm performance is a multidimensional construct, future studies can operationalize it across additional dimensions. For instance, firm performance can be measured using financial or strategic dimensions [61] or using the three general dimensions of financial performance (e.g., accounting-based measures such as ROA, ROE, ROS), business performance (e.g., market-based measures such as market share, sales growth, diversification, product development), and organizational effectiveness (e.g., stakeholder-based measures such as employee satisfaction, social responsibility) [60]. Relatedly, as customer satisfaction precedes the financial performance indicators used in this study, future studies can extend our model to include customer satisfaction by combining the TEJ database with survey data. Fourth, although our results indicate that clicks-and-mortar firms do not necessarily produce greater firm performance than bricks-and-mortar firms due to the increased management complexity, we did not directly measure the costs associated with this increased complexity in adopting a multichannel strategy (e.g., advertising, social media use, online order management, the allotment of sales performance between internal units in the case of physical stores that offer delivery for 
online orders). Future studies could directly measure management complexity and examine whether it is more pronounced for bricks-and-mortar or pure-click firms when they choose to go clicks and mortar. Fifth, given that there are too many categories of industry, the data currently collected may not be able to control the impact of all industries. Future research may improve this problem and use industry as a control variable. Moreover, the data was collected between 2005 and 2014, and is treated as cross-sectional. The channel type of some companies may have changedduring this period. Future longitudinal studies are suggested to examine the impact on financial performance from such transformation of certain companies, or to compare their performances before and after the transformation. Finally, this study adopts regression analysis to investigate the relative financial performance of three company groups; it is suggested that future studies use panel analysis for the cross-sectional data to corroborate our research findings.

\section{Conclusions}

This study compares the relative performance of bricks-and-mortar, clicks-and-mortar, and pure-click types of channel platforms in service firms. Based on the findings, firms with the clicks-and-mortar type of channel platform present higher efficiency than firms with the pure-click type of channel platform. Pure-click firms need to improve their accounts receivable turnover ratio and total assets turnover. Thus, our results suggest pure-click service firms integrate offline platform to its online counterpart to enhance financial performance. However, for bricks-and-mortar service firms, based on findings of this study and prior studies, it is not certain whether the integration of online channel platforms to the offline counterpart can improve the financial performance. This issue deserves further future investigation taking into consideration the complexity in managing different types of channel platforms. Finally, this study calls for further studies that address the current research limitations.

Author Contributions: Conceptualization, methodology, writing-review and editing-I.Y.L.C., Y.-S.W.; investigation, supervision, validation-I.Y.L.C.; data collection, formal analysis, writingoriginal draft preparation-I.Y.L.C., B.-R.L. All authors have read and agreed to the published version of the manuscript.

Funding: This research received no external funding.

Institutional Review Board Statement: Not applicable.

Informed Consent Statement: Not applicable.

Data Availability Statement: No new data were created or analyzed in this study. Data sharing is not applicable to this article.

Acknowledgments: The authors would like to thank Timmy H. Tseng for his kind help on providing insightful suggestions for improving this manuscript.

Conflicts of Interest: The authors declare no conflict of interest.

\section{References}

1. Shen, X.L.; Li, Y.J.; Sun, Y.; Wang, N. Channel integration quality, perceived fluency and omnichannel service usage: The moderating roles of internal and external usage experience. Decis. Support Syst. 2018, 109, 61-73. [CrossRef]

2. Wang, S. Foreign retailers in post-WTO China: Stories of success and setbacks. Asia Pac. Bus. Rev. 2009, 15, 59-77. [CrossRef]

3. Suh, Y.G.; Howard, E. Restructuring retailing in Korea: The case of Samsung-Tesco. Asia Pac. Bus. Rev. 2009, 15, 29-40. [CrossRef]

4. Yoon, J.; Suh, M.G. The key elements of strategic leadership capabilities to the latecomer firm: The case of RT Mart's success in the Chinese retail industry. Asia Pac. Bus. Rev. 2021, 27, 29-52. [CrossRef]

5. Business Insider. Amazon is Opening its First Cashier-less Retail Store in Seattle. 2018. Available online: http://www. businessinsider.com/amazon-go-first-retail-store-in-seattle-2018-1 (accessed on 27 March 2018).

6. Lashinsky, A. Alibaba Has Ambitious, Amazon-Like Offline Plans I Fortune [WWW Document]. 2017. Available online: http:/ / fortune.com/2017/12/12/alibaba-amazon-supermarket/ (accessed on 15 March 2018).

7. Chen, Q.; Zhang, N. Does e-commerce provide a sustained competitive advantage? An investigation of survival and sustainability in growth-oriented enterprises. Sustainability 2015, 7, 1411-1428. [CrossRef] 
8. Chun, S.H. E-commerce liability and security breaches in mobile payment for e-business sustainability. Sustainability $2019,11,715$. [CrossRef]

9. Goersch, D. Multi-channel integration and its implications for retail web sites. In Proceedings of the 10th European Conference on Information System, ECIS, Gdansk, Poland, 6-8 June 2002; pp. 748-758.

10. Enders, A.; Jelassi, T. The converging business models of Internet and bricks-and-mortar retailers. Eur. Manag. J. 2000, 18, 542-550. [CrossRef]

11. Herhausen, D.; Binder, J.; Schoegel, M.; Herrmann, A. Integrating bricks with clicks: Retailer-level and channel-level outcomes of online-offline channel integration. J. Retail. 2015, 91, 309-325. [CrossRef]

12. Shannon, S. Cartier Talks about Cracking China with WeChat. Financial Times. 2017. Available online: https://www.ft.com/ content/ea5402ae-e795-11e6-967b-c88452263daf (accessed on 18 March 2018).

13. Berg, U.; Tornblad, J. Decorating Omnichannels: Shedding Light on the Consumer Perspective on Omnichannel Behavior. Master's Thesis, Uppsala University, Uppsala, Sweden, 2017.

14. Juaneda-Ayensa, E.; Mosquera, A.; Sierra Murillo, Y. Omnichannel customer behavior: Key drivers of technology acceptance and use and their effects on purchase intention. Front. Psychol. 2016, 7, 1-11. [CrossRef] [PubMed]

15. Yurova, Y.; Rippé, C.B.; Weisfeld-Spolter, S.; Sussan, F.; Arndt, A. Not all adaptive selling to omni-consumers is influential: The moderating effect of product type. J. Retail. Consum. Serv. 2017, 34, 271-277. [CrossRef]

16. Zhang, M.; Ren, C.; Wang, G.A.; He, Z. The impact of channel integration on consumer responses in omni-channel retailing: The mediating effect of consumer empowerment. Electron. Commer. 2018, 28, 181-193. [CrossRef]

17. Park, S.; Lee, D. An empirical study on consumer online shopping channel choice behavior in omni-channel environment. Telemat. Inform. 2017, 34, 1398-1407. [CrossRef]

18. Myung, K.; Narcyz, R. Investigating the impact of firm strategy-click-and-brick, brick-and-mortar, and pure-click-on financial performance. J. Inf. Technol. Theory Appl. 2009, 10, 4-18. Available online: https://aisel.aisnet.org/jitta/vol10/iss2/2 (accessed on 25 February 2021).

19. Pauwels, K.; Neslin, S.A. Building With Bricks and Mortar: The Revenue Impact of Opening Physical Stores in a Multichannel Environment. J. Retail. 2015, 91, 182-197. [CrossRef]

20. $\mathrm{Du}, \mathrm{K}$. The impact of multi-channel and multi-product strategies on firms' risk-return performance. Decis. Support Syst. 2018, 109, 27-38. [CrossRef]

21. Bernstein, F.; Song, J.S.; Zheng, X. “Bricks-and-mortar" vs. “clicks-and-mortar": An equilibrium analysis. Eur. J. Oper. Res. 2008, 187, 671-690. [CrossRef]

22. Katz, M.; Shapiro, C. Network externalities, competition and compatibility. Am. Econ. Rev. 1985, 75, 424-440.

23. Lin, K.Y.; Lu, H.P. Why people use social networking sites: An empirical study integrating network externalities and motivation theory. Comput. Hum. Behav. 2011, 27, 1152-1161. [CrossRef]

24. Kulkarni, M.; Mahajan, S. A Textbook of Management Accounting, 1st ed.; NiraliPrakashan: Pune, India, 2008.

25. Cao, L.; Li, L. The impact of cross-channel integration on retailers' sales growth. J. Retail. 2015, 91, 198-216. [CrossRef]

26. Alrafadi, K.M.; Md-Yusuf, M. Evaluating the performance of Libyan banks using return on investment. Am. J. Econ. Bus. Adm. 2013, 5, 84-88. [CrossRef]

27. Keasey, K.; McGuinness, P. The failure of UK industrial firms for the period 1976-1984, logistic analysis and entropy measures. J. Bus. Finan. Account. 1990, 17, 119-135. [CrossRef]

28. Pettersson, F.; Winslott Hiselius, L.; Koglin, T. E-commerce and urban planning-comparing knowledge claims in research and planning practice. Urban Plan. Transp. Res. 2018, 6, 1-21. [CrossRef]

29. Charlesworth, A. Digital Marketing: A Practical Approach, 2nd ed.; Routledge: New York, NY, USA, 2014.

30. Koo, C.M.; Koh, C.E.; Nam, K. An examination of Porter's competitive strategies in electronic virtual markets: A comparison of two on-line business models. Int. J. Electron. Commer. 2004, 9, 163-180. [CrossRef]

31. Mahadevan, B. Business models for Internet-based e-commerce: An anatomy. Calif. Manag. Rev. 2000, 42, 55-69. [CrossRef]

32. Kim, E.; Park, M.C.; Lee, J. Determinants of the intention to use Buy-Online, Pickup In-Store (BOPS): The moderating effects of situational factors and product type. Telemat. Inform. 2017, 34, 1721-1735. [CrossRef]

33. Ailawadi, K.L.; Farris, P.W. Managing multi-and omni-channel distribution: Metrics and research directions. J. Retail. 2017, 93, 120-135. [CrossRef]

34. Verhoef, P.C.; Kannan, P.K.; Inman, J.J. From multi-channel retailing to omni-channel retailing: Introduction to the special issue on multi-channel retailing. J. Retail. 2015, 91, 174-181. [CrossRef]

35. Brynjolfsson, E.; Hu, Y.J.; Rahman, M.S. Competing in the age of omnichannel retailing. MIT Sloan Manag. Rev. 2013, 54, 23-29.

36. Piotrowicz, W.; Cuthbertson, R. Introduction to the special issue information technology in retail: Toward omnichannel retailing. Int. J. Electron. Commer. 2014, 18, 5-16. [CrossRef]

37. Wu, I.L.; Wu, S.M. A strategy-based model for implementing channel integration in e-commerce: An empirical examination. Internet Res. 2015, 25, 239-261. [CrossRef]

38. Bendoly, E.; Blocher, J.D.; Bretthauer, K.M.; Krishnan, S.; Venkataramanan, M.A. Online/in-store integration and customer retention. J. Serv. Res. 2005, 7, 313-327. [CrossRef]

39. Glushko, R.J.; Tabas, L. Designing service systems by bridging the "front stage" and "back stage". Inf. Syst. E-Bus. Manag. 2009, 7, 407-427. [CrossRef] 
40. Patrício, L.; Fisk, R.P.; Falcão e Cunha, J. Designing multi-interface service experiences: The service experience blueprint. J. Serv. Res. 2008, 10, 318-334. [CrossRef]

41. Hagiu, A.; Wright, J. Multi-sided platforms. Int. J. Ind. Organ. 2015, 43, 162-174. [CrossRef]

42. Ho, B.Q.; Inoue, Y. Driving network externalities in education for sustainable development. Sustainability 2020, $12,8539$. [CrossRef]

43. Zhang, X.; Tsai, F.S.; Lin, C.C.; Cheng, Y.F.; Lu, K.H. Fraud, economic versus social-psychological losses, and sustainable e-auction. Sustainability 2018, 10, 3130. [CrossRef]

44. Yang, J.; Mai, E. Experiential goods with network externalities effects: An empirical study of online rating system. J. Bus. Res. 2010, 63, 1050-1057. [CrossRef]

45. Besen, S.M.; Farrell, J. Choosing How to Compete: Strategies and tactics in standardization. J. Econ. Perspect. 1994, 8, 117-131. [CrossRef]

46. Gatignon, H.; Robertson, T.S. A propositional inventory for new diffusion research. J. Consum. Res. 1985, 11, 849-867. [CrossRef]

47. Valente, T.W. Networks Models of the Diffusion of Innovations; Hampton Press, Inc: Cresskill, NJ, USA, 1995.

48. Berry, L.L.; Bolton, R.N.; Bridges, C.H.; Meyer, J.; Parasuraman, A.; Seiders, K. Opportunities for innovation in the delivery of interactive retail services. J. Interact. Mark. 2010, 24, 155-167. [CrossRef]

49. Neslin, S.A.; Grewal, D.; Leghorn, R.; Shankar, V.; Teerling, M.L.; Thomas, J.S.; Verhoef, P.C. Challenges and opportunities in multichannel customer management. J. Serv. Res. 2006, 9, 95-112. [CrossRef]

50. Calder, B.J.; Malthouse, E.C. Managing media and advertising change with integrated marketing. J. Advert. Res. 2005, 45, 356-361. [CrossRef]

51. Morgan, R.M.; Hunt, S.D. The commitment-trust theory of relationship marketing. J. Mark. 1994, 58, 20-38. [CrossRef]

52. Payne, A.; Frow, P. The role of multichannel integration in customer relationship management. Ind. Market Manag. 2004, 33, 527-538. [CrossRef]

53. Stone, M.; Hobbs, M.; Khaleeli, M. Multichannel customer management: The benefits and challenges. J. Database Mark. Cust. Strategy Manag. 2002, 10, 39-52. [CrossRef]

54. Lin, F.; Liang, D.; Chen, E. Financial ratio selection for business crisis prediction. Expert Syst. Appl. 2011, 38, 15094-15102. [CrossRef]

55. Siddik, M.; Alam, N.; Kabiraj, S.; Joghee, S. Impacts of capital structure on performance of banks in a developing economy: Evidence from Bangladesh. Int. J. Financ. Stud. 2017, 5, 13. [CrossRef]

56. Madsen, C.Ø.; Kræmmergaard, P. Channel choice: A literature review. In Proceedings of the International Conference on Electronic Government; Springer: Berlin/Heidelberg, Germany, 2015; pp. 3-18.

57. Ministry of Economic Affairs E-commerce Development. E-commerce Development and Promotion Policy Report. 2016. Available online: http:/ / www.ey.gov.tw (accessed on 23 December 2020).

58. National Development Council. Macroeconomic Indices. 2017. Available online: https://www.ey.gov.tw/state/News_Content3 .aspx?n=3F00F60B9FC304D7\&sms=BEB2957A1275C7C1\&s=2FE35E5B857F7A92 (accessed on 25 March 2018).

59. Huang, G.; Song, F.M. The financial and operating performance of China's newly listed H-firms. Pac. Basin. Financ. J. 2005, 13, 53-80. [CrossRef]

60. Venkatraman, N.; Ramanujam, V. Measurement of business performance in strategy research: A comparison of approaches. Acad. Manag. Rev. 1986, 11, 801-814. [CrossRef]

61. Peng, M.W.; Luo, Y. Managerial ties and firm performance in a transition economy: The nature of a micro-macro link. Acad. Manage. J. 2000, 43, 486-501.

62. Weil, R.; Schipper, K.; Francis, J. Financial Accounting: An Introduction to Concepts, Methods, and Uses; South-Western Cengage Learning: Mason, OH, USA, 2013.

63. Demeter, K. Manufacturing strategy and competitiveness. Int. J. Prod. Econ. 2003, 81, 205-213. [CrossRef]

64. Bodie, Z.; Kane, A.; Marcus, A. Investments, 5th ed.; McGraw-Hill Companies: New York, NY, USA, 2002.

65. Baker, H.K.; Powell, G. Understanding Financial Management: A Practical Guide; Wiley: Hoboken, NJ, USA, 2009.

66. Stratopoulos, T.; Dehning, B. Does successful investment in information technology solve the productivity paradox? Inform. Manag. 2000, 38, 103-117. [CrossRef]

67. Guthrie, J.P.; Datta, D.K. Dumb and dumber: The impact of downsizing on firm performance as moderated by industry conditions. Organ. Sci. 2008, 19, 108-123. [CrossRef]

68. Fama, E.F.; French, K.R. The cross-section of expected stock returns. J. Financ. 1992, 47, 427-465. [CrossRef]

69. Wang, H.; Choi, J.; Li, J. Too little or too much? Untangling the relationship between corporate philanthropy and firm financial performance. Organ. Sci. 2008, 19, 143-159. [CrossRef]

70. Lundvall, K.; Battese, G.E. Firm size, age and efficiency: Evidence from Kenyan manufacturing firms. J. Dev. Stud. 2000, 36, 146-163. [CrossRef]

71. Mehran, H. Executive compensation structure, ownership, and firm performance. J. Financ. Econ. 1995, 38, 163-184. [CrossRef]

72. Waddock, S.A.; Graves, S.B. The corporate social performance-financial performance link. Strateg. Manag. J. 1997, 18, 303-319. [CrossRef]

73. Richard, O.C.; Johnson, N.B. Strategic human resource management effectiveness and firm performance. Int. J. Hum. Resour. Manag. 2001, 12, 299-310. [CrossRef] 
74. Jensen, M.C. Agency costs of free cash flow, corporate finance, and takeovers. Am. Econ. Rev. 1986, 76, 323-329.

75. $\mathrm{Ng}, \mathrm{C}$.Y. An empirical study on the relationship between ownership and performance in a family-based corporate environment. JAAF 2005, 20, 121-146. [CrossRef]

76. Claessens, S.; Djankov, S. Enterprise performance and management turnover in the Czech Republic. Eur. Econ. Rev. 1999, 43, 1115-1124. [CrossRef]

77. Gallino, S.; Moreno, A. Integration of online and offline channels in retail: The impact of sharing reliable inventory availability information. Manag. Sci. 2014, 60, 1434-1451. [CrossRef]

78. Falk, T.; Schepers, J.; Hammerschmidt, M.; Bauer, H.H. Identifying cross-channel dissynergies for multichannel service providers. J. Serv. Res. 2007, 10, 143-160. [CrossRef]

79. Van Birgelen, M.; De Jong, A.; De Ruyter, K. Multi-channel service retailing: The effects of channel performance satisfaction on behavioral intentions. J. Retail. 2006, 82, 367-377. [CrossRef]

80. Xing, Y.; Grant, D.B.; McKinnon, A.C.; Fernie, J. The interface between retailers and logistics service providers in the online market. Eur. J. Mark. 2011, 45, 334-357. [CrossRef]

81. Taipei Times. EDITORIAL: Reshaping Taiwan's Supply Chain. 2020. Available online: https://www.taipeitimes.com/News/ editorials/archives/2020/10/26/2003745801 (accessed on 13 December 2020). 